\title{
BUTTERFLIES OF UGANDA: MEMORIES OF A CHILD SOLDIER
}

\section{Darin Dahms and Sönke C. Weiss}

Joh Brendow \& Sohn Verlag GmbH

2007

140 pages

ISBN 3865062040, 9783865062048

"I was conceived in rape." ${ }^{1}$ At least for this reviewer, this is one of the most powerful, hard-hitting opening lines of any book he has read to date. Moreover, from there this powerful text continues to hold the reader captive, and refuses to allow him or her to fall back in a slumber of indifference.

Evil prevails when good men (and women) do nothing, said Edmund Burke. ${ }^{2}$ Far be it from this reviewer to declare the following list of most wanted war criminals "evil". It is the responsibility of the International Criminal Court (ICC or ICCt) and similar bodies to decide upon the war villain status of Félicien Kabuga, multimillionaire Rwandan businessman, Bosco Ntaganda, military chief of staff of the National Congress for the Defence of the People (CNDP), a militia group based in the Democratic Republic of the Congo (DRC), Ratko Mladic, Chief of Staff of Bosnian Serb Army during the Bosnian War, Aribert Heim, Nazi doctor at Mauthausen concentration camp, Omar Hassan al-Bashir, President of Sudan, Joseph Kony, leader of Uganda's rebel Lord's Resistance Army (LRA). ${ }^{3}$

Like the authors of Butterflies of Uganda, it is the objective of this review, however, to put the issue of war crimes, and in particular, child soldiering, out there for good people to read, digest and ultimately, to act upon. Media criminals have a tendency to become exactly that: they take on a digital life, and their crimes, a virtual nature. One clicks on their names on the Internet and are hyperlinked to anything from chat groups infested with either hate speech or love speech for the same person listed above, to peer-reviewed articles on the topic of war crimes, to unsavoury YouTube videos, and from there as far as one wants to travel mentally and consciously away from Kony the (alleged) war criminal and the acute, inhumane consequences of his self-proclaimed divine status.

Darren Dahms and Sönke Weiss bring Kony back to life, and earth. Better (worse?) still, they drive his actions home,

Scientia Militaria, South African Journal of Military Studies, Vol 40, Nr 2, 2012, pp. 169-170. doi: $10.5787 / 40-2-1002$ right into the reader's flesh and bone. When Kony is reported to have said something, it somehow carries less effect than when student $\mathrm{X}$ reads it aloud in a group of 130 military soldiers who either have been deployed, or are 
destined to be deployed in Uganda ${ }^{4}$ and other countries plagued by war crimes, in particular, child soldiering. Soldier feedback to Butterflies of Uganda continuously echoes the following verbatim sentiment: "Before I read your book or started with this course I had a narrowed vision on child soldiering, and even worse knew very little about child soldiering I never even thought that children could be taught to be combatants. ${ }^{5}$

Butterflies of Uganda "is intended to give children a voice, to advocate against the use of child soldiers and to campaign for the end of war". ${ }^{6}$ Kony, if found guilty of war crimes, will not be the first, nor the last to commit such crimes or to be charged and convicted for doing so. However, perhaps Butterflies around the world will fly once more when "good people" (soldiers) who read Butterflies of Uganda will no longer know nothing and thus "do nothing" when confronted with the harsh realities of civil war upon deployment in civil war-stricken countries or regions.

Butterflies of Uganda was first staged as a play in Los Angeles. It was selected as one of the 10 best plays of 2007. It was also nominated for the Pulitzer Prize, as well as six awards of the US National Association for the Advancement of Coloured People. It is also available on DVD. ${ }^{7}$

Gerhard van Zyl, Department of Languages and Culture, Faculty of Military Science, University of Stellenbosch

\section{Endnotes}

${ }^{1}$ Opening line of Butterflies of Uganda.

${ }^{2}$ Famous quote by Edmund Burke, Irish political philosopher, 12 January $1729-9$ July 1797.

3 "The list: World's six most wanted war criminals". Foreign Policy On-line. 2008. <http://www.foreignpolicy.com/articles/2008/08/03/the_list_the_worlds_six _most_wanted_war_criminals> Accessed on 7 May 2012.

${ }^{4}$ Benton, S. "Cabinet approves SANDF deployment in Northern Uganda". All Africa On-line. 2008. <http://allafrica.com/stories/200803200328.html> Accessed on 7 May 2012.

${ }^{5}$ Anonymous student. Verbatim feedback to reading the text, Butterflies of Uganda, as part of the English 144 course curriculum at the Faculty of Military Science, Stellenbosch University, 2009.

6 Tentena, P. Butterflies of Uganda DVD launched. New Vision. 2008. ${ }^{7}$ Ibid. <http://www.newvision.co.ug/PA/9/507/660430> Accessed on 7 May 2012. 